\title{
Extracción de ácidos nucleicos de una lesión periapical sin antecedente de endodoncia: reporte de caso
}

\author{
Nucleic acid extraction from a periapical lesion without a background of endodontics: \\ case report
}

\author{
María Eugenia Sáenz-Torres', Sandra Milena Alonso-González¹
}

Para citar este artículo: Sáenz-Torres ME, Alonso-González SM. Extracción de ácidos nucleicos de una lesión periapical sin antecedente de endodoncia. UstaSalud 2016;15:49-56.

Licencia Creative Commons \begin{abstract}
(c) (1) (\$) lo tanto, los lectores pueden acceder libremente a los artículos en su formato .pdf, igualmente podrán descargarlos y difundirlos; sin embargo no podrán modificarlos o
\end{abstract} alterarlos, adicionalmente se debe reconocer la autoría de las personas que figuran en las publicaciones, pero estas no podrán comercializadas.

\section{RESUMEN}

Objetivo: el propósito de este estudio in vitro, fue extraer el Ácido Desoxirribonucleico (DNA) de una lesión periapical y amplificar un fragmento de DNA de la subunidad ribosomal 16s bacteriano (DNAr 16s), utilizando la prueba de Reacción en Cadena de la Polimerasa (PCR) y electroforesis.

Materiales y métodos: se analizó una muestra obtenida de un paciente al cual se aplicó la técnica de columnas de Silice para la extracción de DNA. Posteriormente la muestra se procesó con QIAamp ${ }^{\circledR}$ aplicando el protocolo correspondiente para confirmar la presencia de bacterias a través de PCR y electroforesis.

Resultados: el volumen de DNA obtenido fue de $61 \mathrm{ng} / \mu \mathrm{L}$ con una pureza de 1,96. El resultado de electroforesis resultó negativo para DNA bacteriano, lo que permitió concluir que no se trasladaron bacterias al periápice de forma mecánica, ya que la muestra se obtuvo de un molar que no tenía antecedente de endodoncia previa.

Conclusión: este resultado mostró que a pesar de la especificidad y sensibilidad de la técnica utilizada, las lesiones periapicales también pueden ser estériles con presencia de tejido de cicatrización, lo cual puede ser explicado por la acción de los macrófagos del huésped como mecanismo de defensa en ausencia de agentes patógenos.

Palabras clave: Granuloma periapical, ADN, electroforesis.

\section{ABSTRACT}

Objective: the purpose of this in vitro study was to extract DNA from a periapical lesion and amplify a fragment of DNA from the bacterial 16s ribosomal subunit (DNAr 16s) using the Polymerase Chain Reaction (PCR) and electrophoresis.

Materials and methods: a sample obtained from a patient, the technique silica columns for DNA extraction was applied was analyzed. Subsequently the sample was processed with QIAamp ${ }^{\oplus}$ applying the corresponding protocol to confirm the bacteria presence by polymerase chain reaction (PCR) and electrophoresis.

Results: the volume of DNA obtained was $61 \mathrm{ng} / \mathrm{uL}$ purity 1.96. The electrophoresis results were negative for bacterial DNA. Which allowed to conclude that bacteria were not transferred to the peri-penice mechanically, since the sample was obtained from a molar that had no previous history of endodontics.

Conclusion: this result showed that although the specificity and sensitivity of the technique used, periapical lesions may also be sterile with the presence of healing tissue, which can be explained by the action of host macrophages as a defense mechanism in absence of pathogens.

Keywords: Periapical granuloma, DNA, electrophoresis.
1 Odontóloga general, estudiante I semestre Maestría en Odontología, docente Facultad de Odontología, Universidad Santo Tomás, Colombia.

Autor de correspondencia:

Sandra Milena Alonso González Correo electrónico: sandra.alonso@ustabuca.edu.co
Recibido para publicación:

12 de febrero de 2016 Aceptado para publicación: 29 de julio de 2016. 


\section{INTRODUCCIÓN}

Las lesiones periapicales crónicas, conocidas comúnmente como granulomas, son consecuencia directa de procesos infecciosos producto de la necrosis pulpar, en los cuales, las bacterias avanzan a través de los canales radiculares hacia la región perirradicular, lo que conlleva la inflamación periapical. Estos eventos presentan la formación de un tejido de reacción de granulación rodeado por una cápsula de tejido conectivo fibroso, donde los linfocitos son las principales células; igualmente se observa la participación de plasmocitos, neutrófilos, histiocitos y, ocasionalmente, mastocitos y eosinófilos ${ }^{1}$.

La agresión al periodonto comienza por la liberación de productos del metabolismo bacteriano como enzimas histolíticas y toxinas, las cuales pasan por el forámen apical hacia el tejido conectivo del ligamento, causando una reacción inflamatoria. Los macrófagos (histiocitos) de la región perirradicular a través del sistema complemento activado por la vía alternativa atacan los antígenos bacterianos, reconociendo elementos de la superficie bacteriana como el receptor de la manosa, del glicano y del CD14, lo que facilita la fagocitosis ${ }^{1}$.

El quiste radicular es uno de los quistes odontogénicos más frecuente dentro de las alteraciones a nivel periarradicular. Generalmente se desarrollan a partir de un granuloma de origen inflamatorio. A nivel histológico se observa una cavidad patológica recubierta por epitelio pavimentoso estratificado de diverso espesor y rodeada por una cápsula de tejido conectivo fibroso con evidencia de abundante infiltrado inflamatorio linfoplasmocítico y presencia ocasional de macrófagos, neutrófilos y eosinófilos ${ }^{1}$.

La fuerte acción mitogénica de las endotoxinas bacterianas produce reacciones sobre las células epiteliales, que conducen a la estimulación de células inflamatorias y no inflamatorias a la síntesis de citoquinas acelerando la proliferación epitelial, lo que hace pensar que las endotoxinas juegan el papel protagónico en el inicio de la patogénesis de estas lesiones peri-radiculares ${ }^{2}$.

Los métodos de biología molecular como la reacción en cadena de la polimerasa (PCR) han aportado considerablemente al análisis de la microflora endodóntica, resultando ser una técnica altamente sensible para revelar la mínima presencia de DNA de los microorganismos presentes en este tipo de infecciones. Es importante resaltar que la sensibilidad y especificidad de los métodos de identificación empleados, al igual que la ubicación geográfica pudieran explicar las diferencias en las prevalencias reportadas en diversos estudios ${ }^{3-9}$.

El cultivo microbiológico de los microorganismos de origen endodóntico puede ser una tarea compleja y difícil, por lo que se han venido utilizando métodos de genética molecular para su identificación en los últimos años. Básicamente, estos métodos analizan el ácido ribonucleico (RNA) RNAr 16S y el ácido desoxiribonucleico (DNA) DNAr $16 \mathrm{~S}^{10}$, a partir de secuenciación para obtener información filogenética y taxonómica de las bacterias. La PCR es un método de diagnóstico molecular y su objetivo principal es detectar el gen RNAr 16S de los principales microorganismos causales de infecciones endodónticas, lo cual ofrece una mayor precisión y un menor tiempo en el hallazgo de patógenos nuevos de conductos radiculares infectados ${ }^{11-12}$.

El análisis molecular de la microbiota asociada con las infecciones endodónticas indica que la diversidad bacteriana es mayor que la descrita en los análisis realizados a través de los métodos de cultivo, y que la estructura de la microbiota difiere significativamente entre las infecciones asintomáticas y sintomáticas ${ }^{13}$. La electroforesis en gel con gradiente de desnaturalización ha sido utilizada para investigar las comunidades bacterianas asociadas a infecciones endodónticas sintomáticas y asintomáticas, donde la microbiota es comparada por el método PCR-DGGE (Reacción en cadena de la polimerasa-Electroforesis en gel con gradiente de desnaturalización $)^{14}$. Además, por análisis molecular se ha encontrado la presencia de anaerobios estrictos como Filifactor alocis, Tannerella forsythia $y$ Treponema denticola en los conductos radiculares infectados con lesión periapical ${ }^{15}$.

Filotipos no cultivados del grupo Synergistes se han identificado como patógenos en la periodontitis apical, utilizando PCR protocolo de 16S RNAr basado en genes específicos ${ }^{16}$. La presencia de especies bacterianas diferentes implicadas en la etiología de las 
infecciones endodónticas fue determinada utilizando técnicas de hibridación DNA-DNA ${ }^{17}$. La extracción y purificación inadecuada de DNA puede resultar en falsos positivos, por lo que se requiere controlar la pérdida de DNA, reacciones cruzadas de DNA y que los cultivos puros de DNA no se mezclen con tejido libre de bacterias $^{18}$. Se determinó que la calidad del DNA extraído de secciones histológicas de las lesiones perirradiculares es excelente para la hibridación DNA-DNA ${ }^{18}$.

Por tanto, el objetivo de este estudio fue extraer el Ácido Desoxirribonucleico (DNA) de una lesión periapical y amplificar un fragmento de DNA de la subunidad ribosomal 16s bacteriano (DNAr 16s) utilizando la prueba de Reacción en Cadena de la Polimerasa (PCR) y electroforesis.

\section{DESCRIPCIÓN DEL CASO}

Se hizo el estudio de un caso donde se analizó una muestra de lesión perirradicular tomada de un molar extraído, al que no se le había realizado endodoncia, perteneciente a un paciente asintomático de 37 años de edad, de sexo masculino y sin compromiso sistémico. El paciente asistió a la consulta odontológica para solicitar la exodoncia del primer molar superior derecho, el cual presentaba una obturación amplia y desadaptada que involucraba las superficies mesial, distal, oclusal y vestibular; la pieza dental requería un tratamiento de rehabilitación oral con núcleo y corona; sin embargo, el paciente reportó que no podía acceder a dicho procedimiento, debido a los costos, por lo tanto se indicó la exodoncia del diente 16. El paciente no refirió sintomatología dolorosa espontánea, clínicamente se observó movilidad dental grado I, sin edema gingival ni presencia de bolsa periodontal.

Radiográficamente se observó a nivel coronal una imagen radiopaca amplia que involucraba las superficies mesial, distal, oclusal y vestibular, compatible con obturación en amalgama. A nivel de los conductos radiculares, no se observó ninguna imagen compatible con material de obturación que sugiriera la realización de un tratamiento de conductos. A nivel periapical se observó una imagen radiolúcida de aproximadamente $1 \mathrm{~cm}$ con bordes definidos, el trabeculado óseo circundante a la imagen radiolúcida no mostró evidencia de anormalidad, en cuanto al espacio del ligamento periodontal este se observó levemente ensanchado.
Se realizó la exodoncia según el protocolo establecido por la institución y posteriormente se realizó una toma de muestra del tejido adherido al ápice de la raíz palatina, se sumergió en un medio de conservación buffer PBS y se almacenó a $-80^{\circ}$.

\section{Extracción de DNA bacteriano}

Para la extracción de ADN se usó el estuche comercial QIAamp ${ }^{\circledR}$ DNA Mini Kits de QIAgen ${ }^{\star}$. Se descongeló la muestra en baño maría, se tomaron $25 \mathrm{mg}$ de su tejido, triturándose en pequeñas porciones y se colocaron en un microtubo de $1,5 \mathrm{ml}$, posteriormente, se adicionaron $180 \mu \mathrm{l}$ de buffer TL (TISULAR LISIS) para luego someter el tubo a ciclos de vortex por 20 segundos y 10 minutos de incubación en seco de manera alterna durante 40 minutos. Posteriormente se adicionaron $20 \mu \mathrm{l}$ de proteinasa $\mathrm{K}$ (para la desnaturalización de la proteína), se agitó en el vortex y se incubó a $56^{\circ} \mathrm{C}$ por 40 minutos, luego se retiró de la incubadora y se adicionaron $180 \mu \mathrm{l}$ de buffer $\mathrm{AL}$, se homogenizó con vortex antes y después de adicionar la lisozima. El siguiente paso consistió en la incubación a $70^{\circ} \mathrm{C}$ por 10 minutos, una vez más se pasó por el vortex y se adicionaron $200 \mu \mathrm{l}$ de etanol absoluto, esta mezcla se vertió a un tubo filtro que posee una membrana tipo sílica, a través de esta los ácidos nucleicos se unen selectivamente a la sílica ayudando a retener el DNA. Después de este proceso la muestra se centrifugó durante 1 minuto a 6000 gr. (8.000 rpm), luego se descartó el filtrado del tubo colector y se colocó la misma membrana de sílica en un nuevo tubo colector de $2 \mathrm{ml}$, seguidamente se adicionaron $500 \mu \mathrm{l}$ de buffer AW1 y se realizó un centrifugado por un minuto a 6000 gr $(8000 \mathrm{rpm})$ se descartó el filtrado del tubo colector y se colocó nuevamente la misma membrana de sílica en un nuevo tubo colector de $2 \mathrm{ml}$, se adicionaron $500 \mu \mathrm{l}$ de buffer AW 2 y se centrifugó a 20.000 gr (14000 rpm) durante 3 minutos y nuevamente se descartó el filtrado, después se pasó la membrana de sílica a otro tubo colector y se aplicaron 200 $\mu \mathrm{l}$ de buffer $\mathrm{AE}$ directamente sobre la membrana para la elución y se centrifugó por 2 minutos a $10.000 \mathrm{rpm}$, este último filtrado no se descartó y se dejó 1 minuto a temperatura ambiente. Posteriormente se realizó un procedimiento en el Nanodrops Thermo Scientific ${ }^{\circ}$ para cuantificar y establecer la pureza de DNA obtenido (Figura 1). 


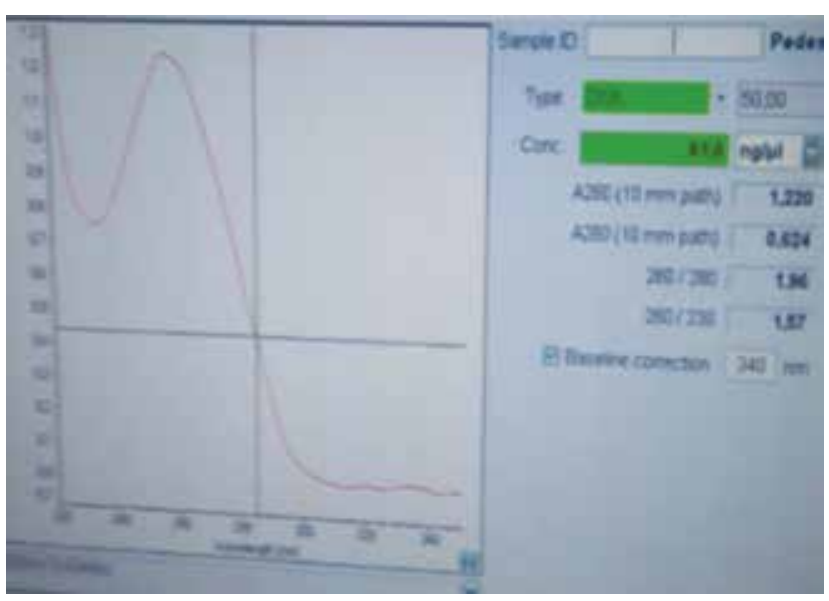

Figura 1. Análisis de pureza de la muestra realizado en equipo Nanodrop Thermo Scientific ${ }^{\circ}$.

\section{Método reacción en cadena de la polimerasa (PCR)}

Para la detección e identificación de las bacterias se procedió a amplificar un fragmento de DNA cromosomal mediante la técnica PCR. Con este método se pretendía amplificar un fragmento de la subunidad ribosomal $16 \mathrm{~S}$ de las eubacterias que corresponde a 1500 pares de base aproximadamente.

El protocolo de PCR utilizado fue el siguiente: se empleó el kit Platinum ${ }^{\circledR}$ PCR SuperMix de la casa comercial Invitrogen by life tecnologie. Durante el procedimiento se utilizaron $20 \mu \mathrm{l}$ del SuperMix, $1 \mu \mathrm{l}$ de forward primer (P27), $1 \mu$ de reverse primer (P152S), los cuales fueron llevados a un minisplit, luego se homogenizó con el vortex y se centrifugó. Posteriormente, se adicionaron $3 \mu \mathrm{l}$ de DNA de la muestra obtenida del tejido en estudio, para un total de $25 \mu$ l.

Las secuencias utilizadas en el ensayo de PCR fueron las siguientes:

- Primers Reverse: 5' - GAA AGG AGG AGA TCC AGC - 3'

- Primers Forward: 5' - GAG TTT GAT CCT GGC TCA - 3'

Las condiciones de la PCR cambian, dependiendo de la enzima y la casa comercial que se esté utilizando.

El paso inicial conocido como la desnaturalización se realizó a $94^{\circ} \mathrm{C}$ durante 2 minutos, para permi- tir abrir la doble cadena de DNA, que está unida por puentes de hidrógeno que se rompen al subir la temperatura. Si hay mucho contenido de Guanina y Citocina en el fragmento que se va a amplificar, la temperatura de $94^{\circ} \mathrm{C}$ debe mantenerse por más tiempo. Se hicieron 45 ciclos, pues a mayor número de ciclos, hay más probabilidades de amplificación del DNA. Se continuó desnaturalizando, por otros $30 \mathrm{seg}$. a $94^{\circ} \mathrm{C}$. En el segundo paso de alineación, la temperatura bajó a $55^{\circ} \mathrm{C}$ por 30 seg., durante este paso, los primeros se adhieren al DNA (es una de las variables más importantes de la reacción del ciclaje).

Posteriormente, se realizó el paso de extensión durante 2 minutos para polimerizar un fragmento de 1500 pares de bases, correspondientes a las Eubacterias. Se hizo otro ciclo a $72^{\circ} \mathrm{C}$ durante 10 minutos, porque hay cadenas que quedan incompletas y esto permite que la polimerasa complete lo que falta. Por último, la muestra se sometió a un ciclo a $4^{\circ} \mathrm{C}$ por tiempo indefinido (Figura 2).

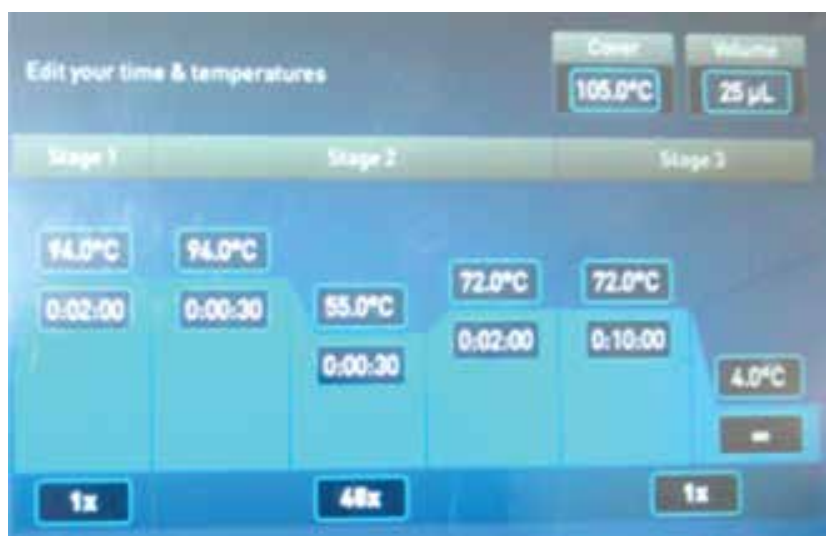

Figura 2. Esquema de programación de temperatura. Termociclador Apply Biosistems ${ }^{\oplus}$

\section{Electroforesis}

Los productos de PCR amplificados fueron evaluados por electroforesis en gel de agarosa al $1 \%$. Una vez finalizada la separación electroforética los geles fueron teñidos con colorante de SYVR GreenÒ.

Para la realización de la electroforesis se utilizó un buffer de carga para que el DNA pudiera correr y se agregaron $11 \mu \mathrm{l}$ de lader, se volvió a centrifugar. A partir del pozo número 2 se agregaron las muestras, con 
un voltaje de $90 \mathrm{w}$, durante 10 minutos y media hora después fueron visualizados en un transiluminador UV.

\section{RESULTADOS}

\section{Extracción DNA}

El resultado de la extracción de DNA y la respectiva cuantificación de micro-volúmen de los ácidos nucleicos arrojados por el Nanodrop fueron de: 61,0ng/ $\mu \mathrm{l}$ con una pureza de1,96 (Figura 1).

\section{Electroforesis}

El resultado arrojado en el proceso de electroforesis fue negativo, es decir, no se evidenció DNA bacteriano de acuerdo con el Ladder Thermo Scientific (Figura 3).

Los controles positivo y negativo de los ensayos fueron coherentes con lo esperado. El positivo marcó la banda amarilla y el negativo no marcó en la banda correspondiente, lo cual muestra confiabilidad en la metodología utilizada.

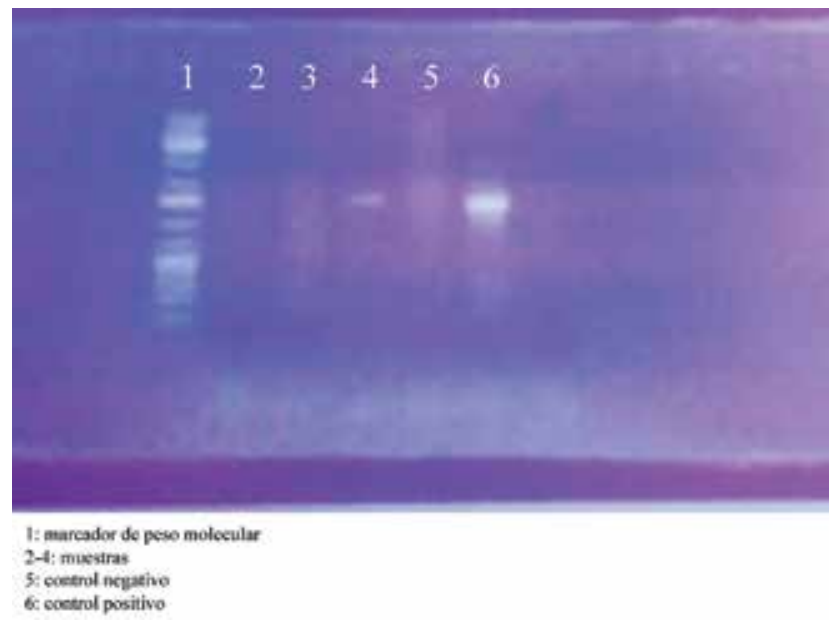

Figura 3. Resultado de la Electroforesis Ladder Thermo Scientific.

\section{DISCUSIÓN}

El objetivo del presente estudio fue evidenciar DNA bacteriano a partir del tejido de una lesión periapical, utilizando una técnica de desnaturalización del DNA a través de PCR y posteriormente una téc- nica de electroforesis. Sin embargo, no se detectó en la muestra el DNA bacteriano, lo que sugiere que hay lesiones que pueden ser estériles o presentar tejido de cicatrización.

Una explicación del fenómeno anterior podría ser que la infección localizada en el periápice es contrarrestada por macrófagos del huésped como respuesta de los mecanismos de defensa propios ${ }^{1}$.

Los resultados obtenidos pueden sugerir que la muestra pudo corresponder a un quiste radicular, cuyo contenido incluye endotoxinas bacterianas, las cuales no se pudieron amplificar, ya que los primeros utilizados eran específicos para bacterias y no para endotoxinas bacterianas.

Por otro lado, la muestra fue obtenida de un molar extraído, sin antecedente de endodoncia previa, lo que nos permite concluir que es probable que no se trasladaron bacterias de la pulpa necrótica al periápice de forma mecánica.

Es preciso mencionar que si se detectó DNA (eucariota) en la muestra, lo que confirma que el DNA no se perdió durante el procedimiento de aislamiento tal y como lo describe Subramanian K, Mickel AK ${ }^{19}$.

Las patologías periapicales generalmente presentan un agente causal de tipo polimicrobiano anaerobio que emana del complejo pulpar; sin embargo, se han aislado bacterias en dientes con pulpas necróticas y coronas aparentemente intactas. Los granulomas o los quistes periapicales producto de la inflamación pulpar se pueden originar por el transporte de irritantes de lesiones cariosas incipientes a través de los túbulos dentinarios al igual que por el paso de microorganismos presentes en los materiales restauradores a través de estos túbulos.

Estudios como el de Siqueira y Roca ${ }^{20}$ donde utilizaron métodos de genética molecular específica concluyen que especies bacterianas como $P$ Propionicus participan en infecciones endodónticas primarias y secundarias y probablemente pueden estar participando en la patogénesis de diferentes lesiones perirradiculares. También Se ha demostrado la utilidad de la PCR para detectar la presencia de cocos anaerobios gram 
positivos de muestras clínicas de dientes extraídos con tejido de granulación y con quistes epiteliales ${ }^{21-22}$.

La naturaleza multimicrobial de las infecciones endodónticas en los conductos radiculares con antecedentes de necrosis pulpar y lesiones perirradiculares evidencia la presencia de microorganismos facultativos, anaerobios y aerobios e incluso especies bacterianas de difícil reconocimiento. Sin embargo, a través del uso de métodos de biología molecular se han podido reconocer bacterias como Fusobacterium nucleatum sp. nucleatum, Fusobacterium periodonticum, Prevotella melaninogénica, Prevotella nigrescens, $y$ Prevotella intermedia ${ }^{22}$.

Seol y colaboradores ${ }^{23}$ con el propósito de detectar la presencia de endodontalis Porphyromonas gingivalis, Prevotella intermedia, $P$. nigrescens y $P$. tannerae tomaron muestras clínicas de manera aséptica de 40 conductos radiculares infectados y abscesos de los pacientes. Las muestras se cultivaron en condiciones anaerobias para la identificación convencional usando un Rapid ID 32 Un kit. Multiplex PCR, luego se procesó utilizando el DNA extraído de cada muestra. Al menos una de las cinco especies de bacterias y negro pigmentado (BPB) se detectaron en el 65\% (26 de 40) de las muestras usando PCR multiplex, y en 15\% (6 de 40) utilizando los procedimientos de cultivo convencionales. Multiplex PCR fue el método más rápido, sensible, específico y eficaz en la detección de BPB que los procedimientos de cultivo convencionales.

Es necesario resaltar que, cuando la banda de 1500 bp se observa en el gel de agarosa, el paso para seguir es la secuenciación del ARNr $16 \mathrm{~S}$ y su respectivo análisis, donde deberá observarse una sola banda (único amplicón) con el tamaño adecuado, permitiendo establecer las relaciones filogenéticas presentes entre los microorganismos bacterianos. Este se convierte en un método eficaz para el estudio de las bacterias, requiriendo las bases de datos disponibles en línea como Genbank del NCBI, aunque las secuencias disponibles en dichas bases presentan un tamaño variable y pueden tener modificaciones en sus datos, suelen analizarse entre 500 y $1.500 \mathrm{pb}^{24}$.

En el campo de la investigación en odontología el método de la técnica PCR se ha convertido en una herramienta indispensable para el diagnóstico de bacte- rias donde su cultivo se hace difícil. Este método ofrece confiabilidad, alta especificidad y sensibilidad. Otra de las ventajas es la facilidad de realización comparada con los cultivos de estos microorganismos ${ }^{25-27}$.

En la actualidad la PCR es implementada con alta frecuencia en laboratorios e instituciones dedicadas a la investigación, quienes han hecho esfuerzos en la adecuación de infraestructura para su aplicación, ya que ofrece ventajas como la especificidad y sensibilidad frente a la ausencia de métodos diagnósticos diferentes y efectivos o para complementar los métodos convencionales. Otra de sus ventajas es la inmediatez en el análisis que entrega un diagnóstico de los agentes patógenos etiológicos para inicio terapéutico a través de nuevas tecnologías ${ }^{26,28-31}$.

Uno de los mayores beneficios se centra en que en esta técnica no se requiere que la secuencia específica, objeto de estudio, esté aislada del resto del genoma y que adicionalmente, una vez completada su replicación, se puede separar del DNA implementando la técnica de electroforesis ${ }^{19-23}$.

Este estudio demostró que en algunas lesiones perirradiculares crónicas como los granulomas y los quistes no se encuentra DNA bacteriano, al utilizar los métodos de biología molecular como la PCR.

Los métodos moleculares que fueron utilizados en este artículo, con el objetivo de verificar a través de extracción de DNA y uso de PCR la presencia de bacterias en lesiones periapicales, son de gran relevancia en el campo de las ciencias básicas e investigación de microorganismos patógenos y en su caracterización, por lo tanto deben ser empleados de acuerdo con los requerimientos y finalidad del estudio por ejecutar.

Sobre la base de estos datos se recomiendan nuevos análisis para determinar la correlación entre los granulomas y los quistes perirradiculares y la presencia de bacterias en estas lesiones utilizando métodos de biología molecular.

\section{BIBLIOGRAFÍA}

1. Pires DA, Alves KM, Gordon MA, Andrade R, Galvao HC. López A. Formación de los granulomas y quistes ra- 
diculares: Una revisión de los aspectos inmunopatológicos. ADM. 2007;3:91-6.

2. Meghji S, Qureshi W, Henderson B, Harris M. The role of endotoxin and cytokines in the pathogenesis of odontogenic cysts. Oral Biol. 1996;41(6): 523-31.

3. Alvarado-Cárdenas G, Hernández-Solís SE, Rueda-Gordillo F, Aguilar-Orozco N. Identificación molecular de Fusobacterium nucleatum en conductos radiculares necróticos de dientes con periodontitis apical crónica. Revista Odontológica Latinoamericana. 2011;3(1):7-10.

4. Medina CMA, Villalobos SM, Arroyo ED, Prez JA, Steffen NS. Enterococcus faecalis en dientes con periodontitis apical asintomática. AMC. 2014;18(4): 415-23.

5. Vinueza MEG, Paredes V, Vasco G, Monar J, Trueba G, Romero TC et al. Identificación molecular y asociación causal de microorganismos presentes en lesiones periapicales refractarias al tratamiento endodóncico. Odonto Investigación. 2016;2(1):2-16.

6. Ozbek SM, Ozbek A, Yavuz MS. Detection of human cytomegalovirus and Epstein-Barr Virus in symptomatic and asymptomatic apical periodontitis lesions by real-time PCR. Med Oral Patol Oral Cir Bucal. 2013;18(5):e811-16.

7. Jakovljevic A, Andric M, Knezevic A, Soldatovic I, Nikolic N, Karalic D et al. Human cytomegalovirus and Epstein-Barr virus genotypes in apical periodontitis lesions. J Endod. 2015;41(11):1847-51.

8. Romero-Salazar DB, Hernández-Solis SE, Rueda-Gordillo F. Identificación mediante PCR de Candida albicans aisladas de conductos radiculares necróticos. Revista Odontológica Latinoamericana. 2013;5(2):51-5.

9. Siqueira, J., Rôças, I., Alves, F., Santos, K. Selected Endodontic Pathogens in the Apical Third of Infected Root Canals: A Molecular Investigation. J Endod 2004;30:638-43.

10. Rolph HJ, Lennon A, Riggio MP, Saunders P, Mackenzie D, Coldero L, Bagg J. Molecular Identification of Microorganisms from Endodontic Infections. J Clin Microbiol. 200;39(9):3282-89.

11. Perea EJ. La flora de la boca en la era de la biología molecular. Oral Patol Oral Cir Bucal. 2004;(9):1-10.

12. Guilarte C, Pardi G, Céspedes C. Cambios taxonómicos en el grupo de bacilos gram negativos de interés en odontología. Acta Odontol Venez. 2005;43(3):327-31.

13. Sakamoto M, Rocas IN, Siqueira JF Jr, Benno Y. Molecular analysis of bacteria in asymptomatic and sympto- matic endodontic infections. Oral Microbiol Inmunol. 2006;21(2):112-22.

14. Siqueira JF Jr, Rocas IN, Rosado AS. Investigation of bacterial communities associated with asymptomatic endodontic infections by denaturing gradient gel electrophoresis fingerprinting approach. Oral Microbiol Inmunol. 2004;19(6):363-70.

15. Gomes BP, Jacinto RC, Pinheiro ET, Sousa EL, Zaia AA, Ferraz CC et al. Molecular analysis of Filifactor alocis, Tannerella forsythia, and treponema denticola associated with primary endodontic infections and failed endodontic treatment. J Endod. 2006;32(10):937-40.

16. Siqueira JF Jr, Rocas IN. Molecular detection and identification of synergistes phylotypes in primary endodontic infections. Oral Dis. 2007;13(4):398-401.

17. Sassone L, Fidel R, Figueiredo L, Fidel S, Faveri M, Feres $M$. Evaluation of the microbiota of primary endodontic infections using checkerboard DNA-DNA hybridization. Oral Microbiol Immunol. 2007;22(6):390-7.

18. Chan S, Mohammed N, Dobeck JM, White RR, Socransky SS, Skobe Z. Evaluation of the whole genome DNADNA hybridization technique to identify bacteria in histological sections of periradicular lesions. J Endod. 2004;30(7):518-22.

19. Subramanian K, Mickel AK. Molecular analisis of persistent periradicular lesions and root ends reveals a diverse microbial profile. J Endod. 2009;35(7):950-7.

20. Siqueira J Jr., Rocas I. Polymerase chain reaction detection of Propionibacterium propionicus and Actinomyces radicidentis in primary and persistent endodontic infections. Oral Surg Oral Med Oral Pathol Oral Radiol. 2003;96(2):215-22.

21. Tüzüner öncül AM, Uzunoglu E, Harahan ZC, Aksoy AM, Kisnisci R, Karaahmetoglu Ö. Detecting Gram-positive anaerobic cocci directly from the clinical samples by multiplex polymerase chain reaction in odontogenic infections. J Oral Maxillofac. Surg. 2015;73(2):259-66.

22. Triches TC, de Figueiredo LC, Feres M, de Freitas SFT, Zimmermann, GS, Cordeiro, MMR. Perfil microbiano de conductos radiculares de los dientes primarios con necrosis pulpar y lesión perirradicular. Diario de Odontología para Niños. 2014;81(1):14-19.

23. Seol JH, Cho BH, Chung CO, Bae KS. Multiplex polymerase chain reaction detection of black-pigmented bacteria in infections of endodontic origin. J Endod. 2006;32(2):110-4. 
24. Poggi H, Guzmán A, García P, Lagos M. PCR universal o de amplio espectro: Un aporte a la detección e identificación de bacterias y hongos en la práctica clínica. Rev. Méd. Chile [Internet]. 2009 Ago [citado 2016 Jun 09];137(8): 1122-1125. Recuperado a partir de: http://www.scielo.cl/scielo.php?script=sci_arttext\&pi$\mathrm{d}=$ S0034-98872009000800020\&lng=es. http://dx

25. Isaza MP, Duncan MS, Kaplan JB, Kachlany SC. Screen for leukotoxin mutants in Aggregatibacter actinomycetemcomitans: genes of the phosphotransferase system are required for leukotoxin biosynthesis. Infect Immun. 2008;76(8):3561-8.

26. Leake JL, Dowd SE, Wolcott RD, Zischkau AM. Identification of yeast in chronic wounds using new pathogen-detection technologies. J Wound Care. 2009;18(3):103-8.

27. Bagherian A, Nematollahi H, Afshari JT, Moheghi $\mathrm{N}$. Comparison of allele frequency for HLA-DR and HLADQ between patients with ECC and caries-free children. J Indian Soc Pedod Prev Dent. 2008;26(1):18-21.
28. John MA, Burden J, Stuart JI, Reyes RC, Lannigan R, Milburn $\mathrm{S}$ et al. Comparison of three phenotypic techniques for detection of methicillin resistance in Staphylococcus $s p p$. reveals a species-dependent performance. J Antimicrob Chemother. 2009;63(3):493-6.

29. Gomes BP, Pinheiro ET, Jacinto RC, Zaia AA, Ferraz CC, Souza-Filho FJ. Microbial analysis of canals of rootfilled teeth with periapical lesions using polymerase chain reaction. J Endod. 2008;34(5):537-40.

30. Yoshida Y, Sasaki T, Ito S, Tamura H, Kunimatsu K, Kato $\mathrm{H}$. Identification and molecular characterization of tryptophanase encoded by tnaA in Porphyromonas gingivalis. Microbiology. 2009;(3):968-78.

31. Gomes BP, Pinheiro ET, Sousa EL, Jacinto RC, Zaia AA, Ferraz CC et al. Enterococcus faecalis in dental root canals detected by culture and by polymerase chain reaction analysis. Oral Surg Oral Med Oral Pathol Oral Radiol Endod. 2006;102(2):247-53. 